\title{
Penyusunan data primer sebagai dasar interoperabilitas sistem informasi pada pemerintah daerah menggunakan diagram RACI (Studi Kasus: Pemerintah Kabupaten Purworejo).
}

\author{
Turah Suhono $^{* * 1}$ dan Hanif Al Fatta ${ }^{2}$
}

1 MTI Universitas Amikom Yogyakarta

Jl. Padjajaran, Ring Road Utara, Kel. Condongcatur, Kec. Depok, Kab.Sleman, Prop. Daerah Istimewa Yogyakarta

turah.suhono@students.amikom.ac.id

2 MTI Universitas Amikom Yogyakarta

Jl. Padjajaran, Ring Road Utara, Kel. Condongcatur, Kec. Depok, Kab.Sleman, Prop. Daerah Istimewa Yogyakarta

hanif.a@amikom.ac.id

\begin{abstract}
Abstrak
Salah satu upaya pemerintah daerah dalam mewujudkan tata kelola pemerintahan yang baik adalah dengan menjalankan e-government. Sistem informasi yang berjalan dengan baik merupakan salah satu faktor utama dalam pelaksanaan e-government. Pemerintah daerah melalui OPD (Organisasi Perangkat Daerah) menjalankan dan mengembangkan sistem informasi sebagai sarana dalam menjalankan tugasnya. Sistem informasi yang dikembangkan OPD saat ini pada umumnya masih bersifat parsial, belum ada perancangan strategis dalam pengembangan sistem informasinya. Salah satu unsur utama yang menjadi bagian tak terpisahkan dari sistem informasi adalah data. Inventaris data yang ada di OPD dengan mengacu pada sistem informasi yang berjalan dan kebutuhan data pada OPD yang berguna untuk penyusunan data primer diperlukan dalam pengembangan sistem informasi. Penelitian ini mengambil studi kasus pada Pemerintah Kabupaten Purworejo, Jawa Tengah, Indonesia. Penelitian diawali dengan inventaris sistem informasi dan data primer di setiap OPD. Pengumpulan data dengan pengisian form survei dilakukan oleh penanggungjawab sistem OPD. Berdasarkan wewenang dan tanggung jawab setiap OPD dilakukan pemetaan sistem informasi dan data primer hasil survei dengan menggunakan tabel RACI (Responsible Accounted Consulted Informed). Hasil analisis didapatkan bahwa $35,1 \%$ atau 45 data primer kelompok kewilayahan, 27,3\% atau 36 data primer kelompok pelayanan, 11,4\% atau 15 data primer kelompok keuangan, 9,1\% atau 12 data primer kelompok keuangan, 6,8\% atau 9 data primer pembangunan daerah dan kepegawaian, 3,8\% atau 5 data primer kelompok administrasi dan manajemen dan 0,8\% atau 1 data primer kelompok legislasi. Berdasarkan hasil pemetaan data primer pada tabel RACI dibuat skema interoperabilitas data dan sistem informasi, sehingga dapat diketahui kebutuhan data dan sistem informasi lintas OPD. Uji validasi data primer dilakukan dengan FGD (Focus Group Discussion) bersama seluruh OPD dan juga dilakukan uji beban serta uji fungsi terhadap interoperabilitas data dengan menggunakan 3 sampel sistem informasi yang telah digunakan pada OPD.
\end{abstract}

Kata Kunci sistem informasi, data primer, opd, raci

\footnotetext{
* Corresponding author.

(c) (i) Suhono. T dan Fatta. A. H.;

licensed under Creative Commons License CC-BY

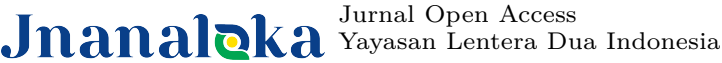




\section{Pendahuluan}

Data primer merupakan persyaratan utama dalam integrasi sistem informasi pemerintah daerah untuk merealisasikan e-government di sebuah pemerintah kabupaten/kota dalam rangka mewujudkan kota pintar (smart city). Penelitian ini dilakukan bertujuan untuk mendapatkan data primer yang digunakan sebagai acuan dalam integrasi sistem informasi di lingkungan Pemerintah Kabupaten Purworejo. Kondisi saat ini data dan sistem informasi di Pemerintah Kabupaten Purworejo masih bersifat parsial di tiap OPD (Organisasi Perangkat Daerah). Pengembangkan sistem informasi secara parsial yang hanya sesuai kebutuhan OPD tanpa memperhatikan kebutuhan data antar OPD menjadikan kendala utama dalam integrasi baik data maupun sistem informasi di lingkungan kabupaten. Pemetaan Data OPD yang dapat dibagi pakai sesuai kebutuhan antar OPD di lingkungan Pemerintah Kabupaten Purworejo merupakan langkah awal dalam integrasi. Belum adanya data primer yang menjadi acuan dasar integrasi data dan sistem informasi, berakibat integrasi sistem informasi antar OPD akan sulit dilakukan.

Berdasarkan data primer dilakukan analisis interoperabilitas sistem informasi dan data. Interoperabilitas didefinisikan sebagai kemampuan data untuk dibagipakaikan antar sistem elektronik yang yang saling berinteraksi [1]. Purworejo smart city sudah mulai diupayakan pencapaiannya sejak diberlakukannya Peraturan Daerah (Perda) Nomor 12 Tahun 2016 [2] dan ditindaklanjuti dengan disusunnyaroadmap smart city Kabupaten Purworejo. Pengambilan kebijakan dalam konteks pendekatan smart city membutuhkan kecepatan ketersediaan supply data. Data tersebut dapat berasal dari berbagai sumber baik dari basis data lingkungan pemerintah sendiri maupun dari pihak di luar pemerintah. Salah satu tantangan dalam pengembangan smart city adalah terkait supply data dan informasi yang cepat dan akurat [3]. Pelaksanaan e-government di Kabupaten Purworejo meliputi : infrastruktur jaringan dan komputer, penyediaan dan pengembangan aplikasi, pengaturan data dan informasi, pengembangan SDM (Sumber Daya Manusia), kelembagaan, keamanan informasi dan pembiayaan [4]. Data primer adalah data yang diambil langsung dari obyek penelitian atau merupakan data yang berasal dari sumber asli atau pertama. Data ini tidak tersedia dalam bentuk file. Pencarian data primer bisa dilakukan dengan cara wawancara atau wawancara langsung dengan responden, melalui telepon, email dan sebagainya. Dalam mengumpulkan data primer, biasanya digunakan instrumen penelitian yang disebut dengan kuesioner [5].

Perlu dilakukan inventaris data apa saja yang ada di setiap OPD Kabupaten Purworejo dengan mengacu pada sistem informasi atau aplikasi yang berjalan selama ini dan juga kebutuhan data yang belum ada di OPD saat ini. Setelah data terkumpul kemudian dipetakan kebutuhan data lintas OPD yang kemudian akan dijadikan data primer. Dengan adanya penyusunan data primer ini maka diharapkan dapat menjadi rujukan bagi pengembangan sistem yang terintegrasi.

Penelitian ini bertujuan untuk penyusunan data primer pada tiap OPD sesuai dengan tugas pokok fungsi dan tanggung jawab nya yang melibatkan OPD lain di lingkungan Pemerintah Kabupaten Purworejo, dan pemetaan interoperabilitas sistem informasi berdasarkan pemetaan data primer. Pengumpulan data dilakukan dengan pengisian form survei oleh 35 OPD dengan melibatkan penanggungjawab sistem di masing-masing OPD. Unsur pimpinan sebagai pengambil kebijakan, unsur Dinas Komunikasi dan Informatika yang kemudian dijadikan sumber data primer. Validasi terhadap data yang terkumpul dilakukan dengan pelaksanaan FGD (Focus Group Discussion). Tabel RACI (Responsible Accounted Consulted Informed) digunakan untuk memetakan data primer, dan berdasarkan pemetaan data primer tersebut dilakukan analisis interoperabilitas sistem informasi antar OPD. 
Pada penelitian yang dilakukan oleh Mochammad Rizki Romdoni [6] melakukan penelitian tentang pengembangan arsitektur berbasis SOA (Service Oriented Architecture) yang diberi nama PIE (Portal Interoperabilitas E-Government) untuk Pemerintah Kota Denpasar dalam integrasi dan berbagi sumber daya antar SKPD (Satuan Kerja Perangkat Daerah) dengan mudah dan dapat diakses serta dimanfaatkan oleh masyarakat. Hasil penelitian ini mengintegrasikan sistem informasi pemerintahan melalui PIE dengan mengikuti prinsip-prinsip dalam SOA. Pada penelitian yang dilakukan oleh [7] tentang penyusunan data primer menggunakan pemetaan diagram RACI yang menghasilkan pemetaan data primer dan juga kamus data. Pada penelitian yang dilakukan oleh [8], melakukan penelitian mengenai faktor yang berkontribusi terhadap interoperabilitas sistem e-Government. Tujuan utama dari penelitian ini adalah untuk mengumpulkan faktor-faktor yang berkontribusi terhadap keberhasilan sistem e-Government pada organisasi.

Perbandingan dengan penelitian ini adalah penyusunan data primer menggunakan pemetaan diagram RACI dan dilanjutkan dengan analisis interoperabilitas sistem informasi. Hasil dari penelitian ini adalah pemetaan data primer dan analisis interoperabilitas sistem informasi yang dapat digunakan sebagai acuan dalam pengembangan sistem informasi yang akan datang.

\section{Metodologi}

Secara umum metode penelitian yang digunakan adalah mengikuti langlah-langkah seperti tertampil dalam Gambar 1. Pada tahap pendahuluan dilakukan penyusunan form survei, pemetaan OPD pada tabel RACI dan pengajuan persetujuan form survei kepada pejabat penanggungjawab di Dinas Komunikasi dan Informatika Kabupaten Purworejo. Setelah mendapatkan persetujuan, form survei dikirimkan kepada seluruh responden dengan pokok isian terkait inventaris sistem informasi dan data, inventaris struktur data dan kebutuhan data antar OPD.

Tahapan wawancara langsung dilakukan ke masing-masing OPD untuk klarifikasi hasil form survei dan melihat kondisi eksisting sistem informasi maupun data yang ada dan klarifikasi terkait kebutuhan data antar OPD dengan berdasarkan pada tugas pokok fungsi masing-masing OPD. Data hasil dari form survei direkap dalam tabel RACI untuk memetakan kewenangan dan tanggung jawab data maupun sistem informasi masing-masing OPD dan juga kebutuhan data lintas OPD.

Pada tahapan selanjutnya dilakukan FGD bersama OPD untuk konfirmasi terhadap hasil pengumpulan data dan rekapitulasi data pada tabel RACI dan juga dilakukan pembahasan bersama terkait kebutuhan data lintas OPD dan rencana pengembangan sistem informasi. Dengan berdasarkan rekapitulasi data pada tabel RACI dan hasil FGD bersama OPD, kemudian dilakukan analisis pada tabel RACI terkait pemetaan wewenang dan tanggung jawab data tiap OPD dan analisis kebutuhan data antar OPD yang akan menjadi dasar pemetaan interoperabilitas data dan sistem informasi. Setelah tahapan analisis interoperabilitas data dan sistem informasi dilakukan pengujian interoperabilitas sistem informasi, pengujian dilakukan terkait uji beban (load test) terhadap sampel sistem informasi yang menjadi provider data interoperabilitas.

FGD kedua dilakukan bersama pejabat dan tim teknis dari Dinas Komunikasi dan Informatika Kabupaten Purworejo untuk memaparkan hasil penelitian mulai dari pengumpulan data sampai analisis interoperabilitas data dan sistem informasi, dan juga pembahasan terkait rencana pengembangan sistem informasi, dimana hasil dari FGD ini akan dijadikan bahan dalam penyusunan kesimpulan. Pada tahapan terakhir adalah penyusunan kesimpulan dan 


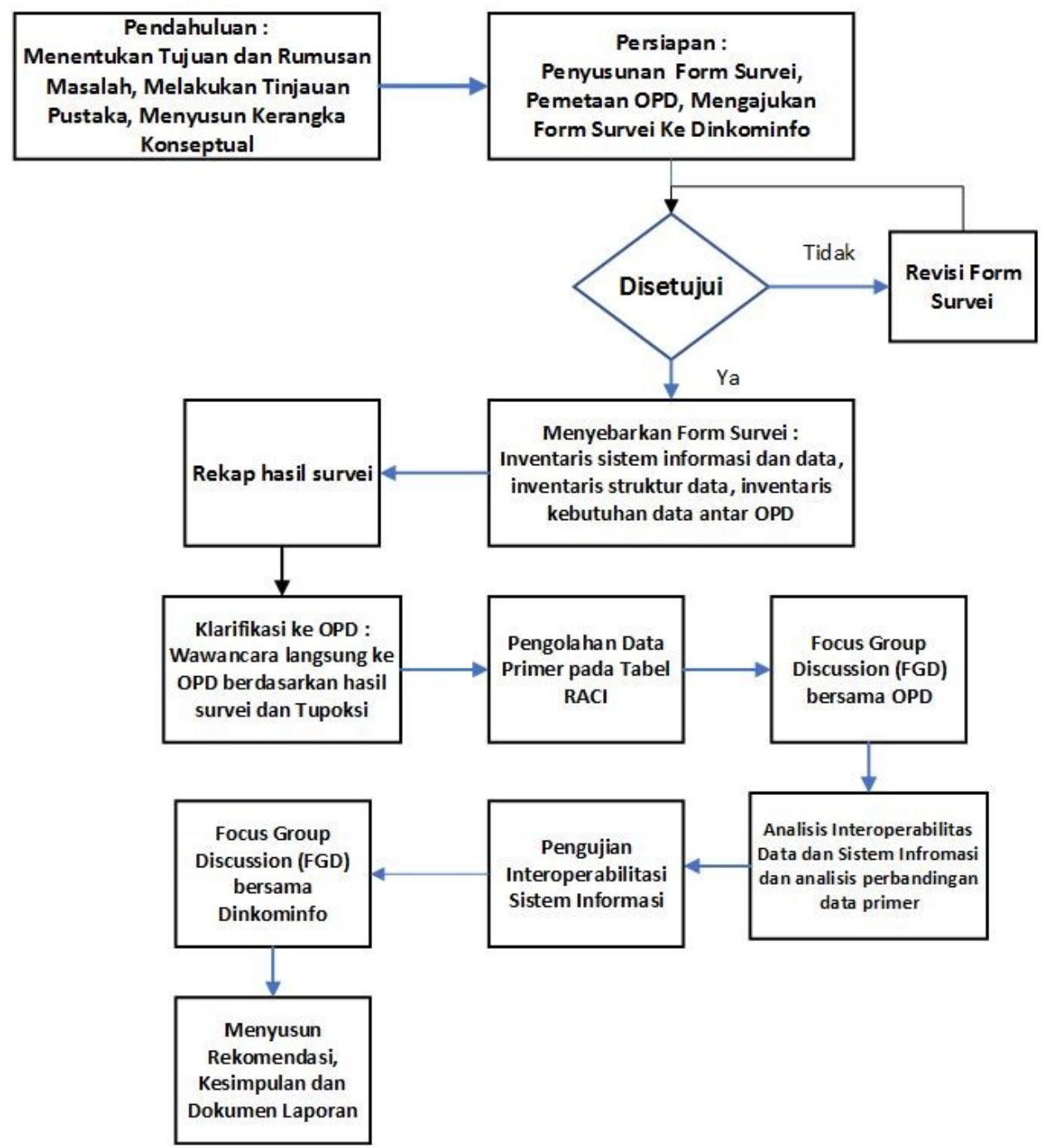

Gambar 1 Langkah penelitian.

laporan dari keseluruhan hasil penelitian.

Pada penelitian ini pengumpulan data dilakukan dengan pengisian form survei secara daring oleh 35 OPD yang ada di lingkungan Pemerintah Kabupaten Purworejo dengan melibatkan penanggungjawab sistem di masing-masing OPD yakni unsur pimpinan sebagai pengambil kebijakan, unsur Dinas Komunikasi dan Informatika yang kemudian dijadikan sumber data primer. Untuk mendukung dan menguatkan penelitian juga melakukan kajian literatur serta peraturan-peraturan yang dikeluarkan oleh Pemerintah Kabupaten Purworejo terkait dengan tugas pokok fungsi tiap OPD yang disebut sumber data sekunder. Data yang dikumpulkan melalui proses survei merupakan data primer yang terkait tugas aktual yang selama ini berjalan di tiap OPD, sedangkan data sekunder yang dijadikan bahan konfirmasi atas kewenangan deskripsi tugas yang ada di Peraturan Bupati terkait dengan tugas pokok fungsi yang diberikan ke tiap OPD.

Teknik analisa data yang digunakan tergantung pada tujuan penelitian serta ketersediaan pengelolaan data. Analisis data yang dilakukan dengan berdasarkan pemetaan data primer pada OPD yang diperoleh melalui proses survei dan telah dikonfirmasi pada tahap FGD. 
Pemetaan data menggunakan tabel RACI yang menggambarkan informasi kolom merupakan OPD yang mempunyai kepentingan terhadap data primer, dan informasi baris merupakan data primer yang dikumpulkan dari tiap OPD sesuai yang diamanahkan. Hasil pemetaan data primer pada tabel RACI dijadikan dasar untuk analisis interoperabilitas, dilakukan analisis vertikal untuk mengetahui informasi atau data yang paling dibutuhkan oleh OPD lain dan analisis horisontal untuk mengetahui OPD yang paling berpengaruh terhadap ketersediaan data primer.

\section{Hasil dan pembahasan}

Pada tahap ini diawali dengan analisa data dan sistem, selanjutnya analisa perumusan rencana strategis sistem informasi, validasi data dengan FGD dan analisa triangulasi. Diagram RACI atau RACI Chart merupakan salah satu alat yang digunakan untuk pengambilan keputusan dan membantu pihak manajemen dalam mengidentifikasikan peran dan tanggung jawab karyawan. RACI yang merupakan singkatan dari Responsible, Accountable, Consulted dan Informed pada penelitian ini disajikan dalam bentuk tabel.

Tabel RACI menggambarkan informasi kolom merupakan OPD yang mempunyai kepentingan terhadap data primer, dan informasi baris merupakan data primer yang dikumpulkan dari tiap OPD sesuai yang diamanahkan. Pertemuan antara baris dan kolom ditandai dengan huruf sesuai dengan peran dan tanggung jawabnya yaitu : Responsible (R) merupakan OPD yang melakukan tugas atau pekerjaan. Accountable (A) merupakan OPD yang menjadi penanggung jawab dan pengambil keputusan terhadap tugas atau pekerjaan tertentu. Consulted (C), yaitu OPD yang memberikan masukan, pendapat atau kontribusi ketika diperlukan pada suatu tugas atau pekerjaan. Sedangkan Informed (I), yaitu OPD yang perlu mengetahui tindakan dan hasil ataupun keputusan yang telah diambil. Hasil analisa pengolahan data di Kabupaten Purworejo dengan diagram RACI ditampilkan pada Tabel 1.

Berdasarkan hasil rekapitulasi data primer dan OPD penanggungjawab data melalui tabel RACI, yang terdiri dari data-data yang menjadi tanggung jawab masing-masing OPD dan saling dipertukarkan antar OPD, didapatkan 134 data yang menjadi kewenangan 35 OPD di lingkungan Pemerintah Kabupaten Purworejo. Terdiri dari 126 data primer atau basis data dan 8 data summary. Pengelompokan data berdasarkan pada 8 kelompok sesuai yang tercantum pada Peraturan Bupati Purworejo [4].

Pada urutan pertama sebesar 35,1\% atau 45 data primer kelompok kewilayahan, 27,3\% atau 36 data primer pelayanan, 11,4\% atau 15 data primer kelompok keuangan, 9,1\% atau 12 data primer kelompok pemerintahan, 6,8\% atau 9 data primer kelompok pembangunan daerah dan kepegawaian, 3,8\% atau 5 data primer kelompok administrasi dan manajemen dan yang terakhir 0,8\% atau 1 data primer kelompok legislasi seperti pada Gambar 2 .

Setelah dilakukan rekapitulasi data, dilakukan analisis data primer secara vertikal dan horisontal. Berdasarkan analisis data primer (analisis vertikal) dalam penelitian ini, dihasilkan 14 data primer yang informasinya (I) paling dibutuhkan oleh OPD lain (memiliki prosentase di atas 50\%,) yaitu : Data Pemeriksaan (97,1\%), Data Sasaran Kinerja Pegawai (97,1\%), Data Pengelolaan Diklat Pegawai (97,1 \%), Data Organisasi Perangkat Daerah (97,1 \%), Data Aduan Masyarakat (97,1\%), Data Produk Hukum (97,1 \%), Data Kegiatan DPRD (97,1 \%), Data Rencana Kerja Tahunan RKPD (97,1 \%), Data RPJMD (97,1 \%), Data SSH dan ASB (97,1\%), Data Summary Kepegawaian Per OPD (97,1\%), Data Arsip (94,3\%), Data Pegawai (94,3\%), Data Kependudukan (62,9\%).

Pada analisis ini juga menyandingkan daftar aplikasi asal dari data primer, dimana ada 2 OPD yang belum mempunyai aplikasi tetapi datanya dibutuhkan oleh semua OPD yaitu 
Penyusunan data primer sebagai dasar interoperabilitas sistem informasi.

Tabel 1 Pengolahan data pada diagram RACI

\begin{tabular}{l|l|c|c|c|c|c|c}
\hline No & OPD & 1 & 2 & 3 & 4 & 5 & 6 \\
\hline 1 & Data Primer & R/A & & & & & \\
2 & Data Kegiatan DPRD & R/A & I & I & I & I & I \\
3 & Data Pemeriksaan & R/I & R/A & R/I & R/I & R/I & R/I \\
4 & Data Sekolah & & $\mathrm{I}$ & $\mathrm{R} / \mathrm{A}$ & $\mathrm{I}$ & & \\
5 & Data Guru Non PNS & & $\mathrm{R} / \mathrm{A}$ & & & & \\
6 & Data Peserta Didik & $\mathrm{R} / \mathrm{A}$ & & & & \\
7 & Data Layanan Kesehatan & & $\mathrm{R} / \mathrm{A}$ & & & \\
8 & Data Penyakit & & $\mathrm{R} / \mathrm{A}$ & & & \\
9 & Data Perijinan Medis & & $\mathrm{R} / \mathrm{A}$ & & & \\
10 & Data Jamkesda & & $\mathrm{R} / \mathrm{A}$ & & & \\
11 & Data Layanan Puskesmas & & $\mathrm{R} / \mathrm{A}$ & & & \\
12 & Data Jalan Kabupaten & & & & $\mathrm{R} / \mathrm{A}$ & $\mathrm{I}$ \\
13 & Data Jembatan & & & & $\mathrm{R} / \mathrm{A}$ & \\
14 & Data Jaringan Irigasi & & & & $\mathrm{R} / \mathrm{A}$ & $\mathrm{I}$ \\
15 & Data Bendungan & & & & $\mathrm{R} / \mathrm{A}$ & \\
16 & Data Bangunan Gedung NegarIa & & & $\mathrm{I}$ & & $\mathrm{R} / \mathrm{A}$ & $\mathrm{I}$ \\
17 & Data Drainase Kota & & & $\mathrm{R} / \mathrm{A}$ & $\mathrm{C} / \mathrm{I}$ \\
18 & Data Tata Ruang & & & $\mathrm{R} / \mathrm{A}$ & $\mathrm{C} / \mathrm{I}$ \\
19 & Data Jalan Lingkungan & & & $\mathrm{C} / \mathrm{I}$ & $\mathrm{R} / \mathrm{A}$ \\
\hline
\end{tabular}

Inspektorat dan Sekretariat DPRD. Berdasarkan Analisis OPD (analisis horisontal) dengan berdasarkan Responsible pada fungsi RACI pada penelitian ini menghasilkan OPD yang paling berpengaruh terhadap ketersediaan data primer yang ada di lingkungan Pemerintah Kabupaten Purworejo.

Adapun OPD tersebut antara lain : Kecamatan (terhadap 92 data primer), Dinas PUPR (terhadap 38 data primer), Dinas Kesehatan (terhadap 36 data primer), Dinas KUKMP (terhadap 36 data primer), (Badan Pendapatan, Pengelolaan Keuangan dan Aset Daerah (terhadap 36 data primer). Dengan berdasarkan analisis tabel RACI dilakukan analisis interoperabilitas data dan sistem informasi untuk mengetahui kebutuhan data lintas OPD, yang akan berimplikasi pada data tersebut untuk dibagipakaikan antar sistem elektronik yang yang saling berinteraksi. Pada analisis ini selain daftar primer, juga dengan menyandingkan

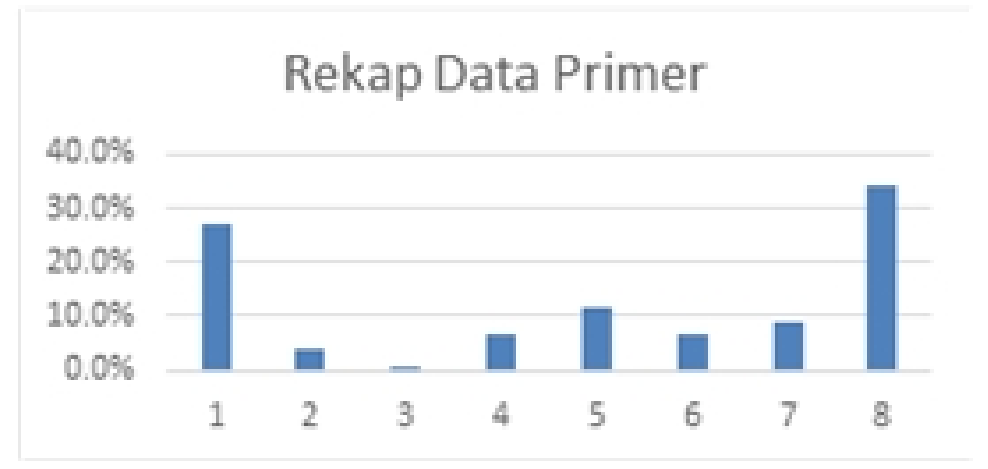

Gambar 2 Rekap data primer per kelompok. 
daftar sistem informasi asal dari data primer.

Dengan berdasarkan hasil dari analisis pada tabel RACI, untuk OPD yang merupakan penanggung jawab data dan sistem informasi diberi tanda warna kuning (hasil analisis bagian dengan tanda "A"), untuk bagian bertanda "I" data primer yang berasal dari sistem informasi diberi tanda warna hijau yang diartikan interoperabilitas terkait sistem informasi, sedangkan data primer yang bukan berasal dari sistem informasi diberi tanda warna merah yang diartikan bahwa interoperabilitas terkait data.

Pengujian interoperabilitas dilakukan dengan uji beban (load testing) beserta uji kesesuaian rekomendasi standar untuk pengiriman data, direktori jaringan, transfer berkas, surat elektronik dan penyamaan waktu [9]. Pada penelitian ini dilakukan pengujian interoperabilitas pada uji beban untuk menguji performance sistem informasi yang berfungsi sebagai provider data dalam proses interoperabilitas, dan pengujian fungsi interoperabilitas untuk membuktikan bahwa tujuan dari interoperabilitas dapat tercapai. Uji beban dilakukan terhadap sampel sistem informasi yang berfungsi sebagai provider data dan aplikasi web service dalam proses interoperabilitas, yaitu Aplikasi SIAK (Sistem Informasi Administrasi Kependudukan) sebagai provider data kependudukan dan Aplikasi Dashboard Web Service sebagai layanan web service pada Dinas Kependudukan dan Pencatatan Sipil untuk pengujian request POST. Adapun konfigurasi yang diperlukan untuk koneksi yaitu: ip address server, port, alamat path untuk request data, dan parameter apa saja yang menjadi request terhadap basis data pada provider data kependudukan dengan terlebih dahulu meminta konfigurasi kepada admin Aplikasi SIAK.

Pada penelitian ini menggunakan tools Aplikasi Apache Jmeter untuk mengukur performance sistem informasi melalui uji beban [10]. Pengujian performance dengan memanfaatkan tools yang ada pada Aplikasi Apache JMeter, dimana hasil pengujian yang akan ditampilkan dapat dipilih sesuai kebutuhan, pada pengujian ini hasil yang ditampilkan yaitu : view results in table, response time graph, summary report. Dengan berdasar pada setting jumlah users: 50 dan loop count: 6 , setelah dilakukan pengujian maka akan ditampilkan sampel pengujian berulang sebanyak 300 pengujian sebagaimana ditunjukan pada Gambar 3.

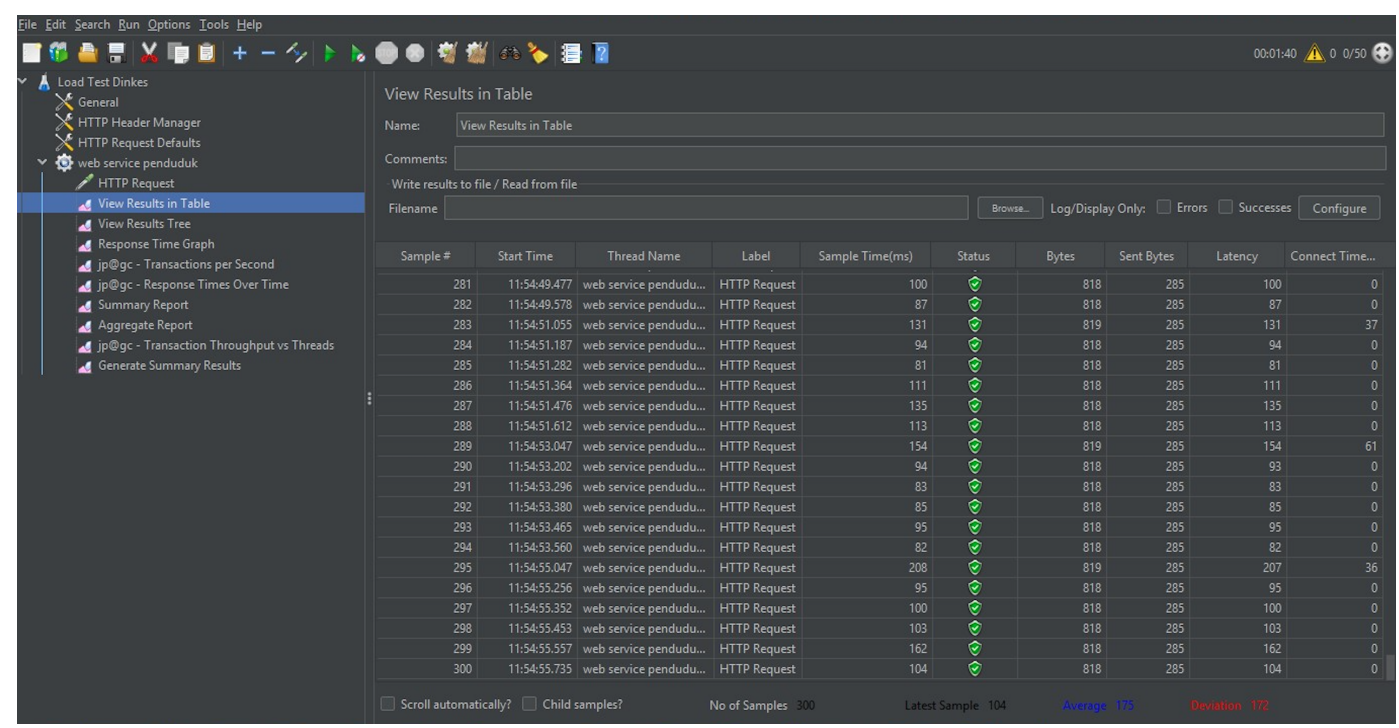

Gambar 3 Hasil pengujian dengan aplikasi Apache Jmeter.

Sedangkan tampilan secara grafik untuk pengujian sebanyak 300 sampel uji ditunjukkan 
pada Gambar 4. Sedangkan rekapitulasi hasil uji dengan pengujian sebanyak 300 sampel uji beban seperti ditunjukkan pada didapatkan hasil average : 175, Min : 78, Max :1302, Standard deviaton : 172.2 , error : $0 \%$, throughput : $3.0 / \mathrm{sec}$, received $\mathrm{kb} / \mathrm{sec}: 2.43$, sent $\mathrm{kb} / \mathrm{sec}: 0.85$, Average bytes : 818.2.

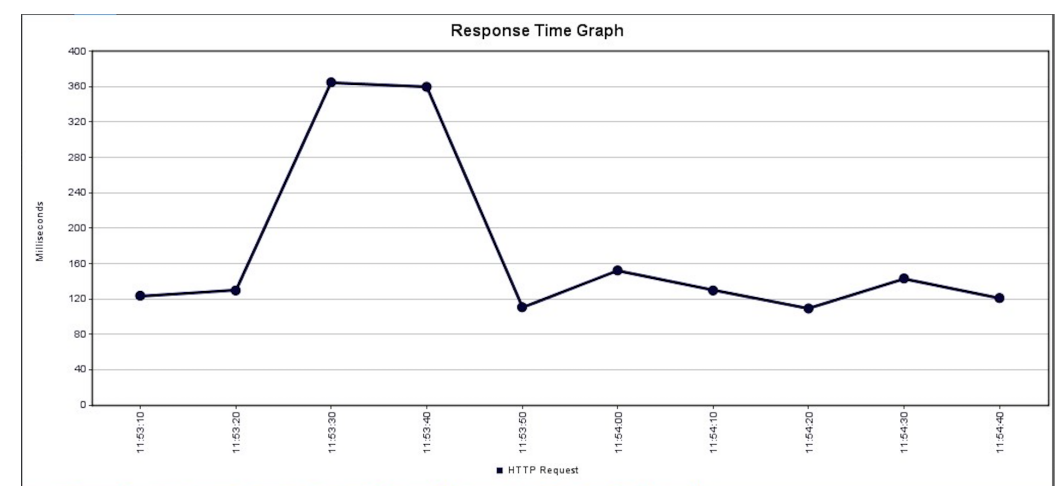

Gambar 4 Tampilan response time graph.

Pengujian fungsi interoperabilitas dalam penelitian ini menggunakan 3 sistem informasi yaitu Aplikasi SIAK sebagai provider data kependudukan dan Aplikasi Dashboard Web Service sebagai layanan web service yang ada pada Dinas Kependudukan dan Pencatatan Sipil, dan 3 aplikasi client yaitu Aplikasi SIMPUS (Sistem Informasi Puskesmas) pada Dinas Kesehatan, dimana aplikasi SIMPUS mempunyai perbedaan platform database dengan Aplikasi SIAK sebagai web service seperti pada Tabel 2, sehingga pembuktian tujuan interoperabilitas sistem informasi dapat tercapai. Ujicoba integrasi Aplikasi SIMPUS dengan Aplikasi SIAK terkait dengan data kependudukan yang ada pada Aplikasi SIAK. Aplikasi SIMPUS mengambil data kependudukan untuk input data pasien.

Tabel 2 Spesifikasi aplikasi uji interoperabilitas

\begin{tabular}{l|l|l|l|l}
\hline OPD & Aplikasi & Spesifikasi & Layanan Data & Keterangan \\
\hline $\begin{array}{l}\text { Dinas Kependu- } \\
\text { dukan dan Penca- } \\
\text { tatan Sipil }\end{array}$ & $\begin{array}{l}\text { Aplikasi Sistem In- } \\
\text { formasi Administra- } \\
\text { si Kependudukan }\end{array}$ & $\begin{array}{l}\text { Pemrograman } \\
\text { PHP - Database } \\
\text { Oracle }\end{array}$ & $\begin{array}{l}\text { Data Kependu- } \\
\text { dukan }\end{array}$ & Provider \\
$\begin{array}{l}\text { Dinas Kependu- } \\
\text { dukan dan Penca- } \\
\text { tatan Sipil }\end{array}$ & $\begin{array}{l}\text { Aplikasi Dashboard } \\
\text { Web Service }\end{array}$ & $\begin{array}{l}\text { ASP - Database } \\
\text { Oracle }\end{array}$ & $\begin{array}{l}\text { Layanan Web Se- } \\
\text { rvice }\end{array}$ & Web Service \\
Dinas Kesehatan & $\begin{array}{l}\text { Aplikasi Sistem In- } \\
\text { formasi Puskesmas }\end{array}$ & $\begin{array}{l}\text { ASP - Database } \\
\text { MySQL }\end{array}$ & $\begin{array}{l}\text { Data Pasien pada } \\
\text { Puskesmas }\end{array}$ & Client \\
\hline
\end{tabular}

Admin aplikasi SIAK memberikan data koneksi ke admin aplikasi client yang meliputi : alamat url server aplikasi SIAK, username dan password. Dalam pengujian ini setting koneksi dilakukan bersama admin aplikasi SIMPUS dengan konfigurasi alamat url : HTTP://103.xxx.xxx.xx:90/DUKCAPIL/GET_JSON/DKK/CALL, username : AGUS, password : xxxxx (disembunyikan). Setelah dilakukan setting konfigurasi koneksi pada aplikasi client, dilakukan uji pengecekan data dengan pemanggilan NIK pada form yang telah dibuat pada aplikasi SIMPUS. NIK yang digunakan untuk pengujian dari aplikasi SIMPUS adalah sama dengan NIK pada waktu pengecekan pada aplikasi SIAK.

Pengujian dilakukan dengan memasukkan NIK pada form, jika ditampilkan data sesuai 
dengan data saat pengecekan pada aplikasi SIAK dan data pada KTP elektronik, maka berhasil dilakukan koneksi data antara aplikasi SIAK dan aplikasi SIMPUS, seperti yang ditampilkan pada Gambar 5. Dengan berhasilnya pemanggilan sampel data pada aplikasi SIAK dari aplikasi SIMPUS, maka pengujian interoperabilitas sistem informasi antara aplikasi SIAK dan aplikasi SIMPUS tersebut berhasil dilakukan.

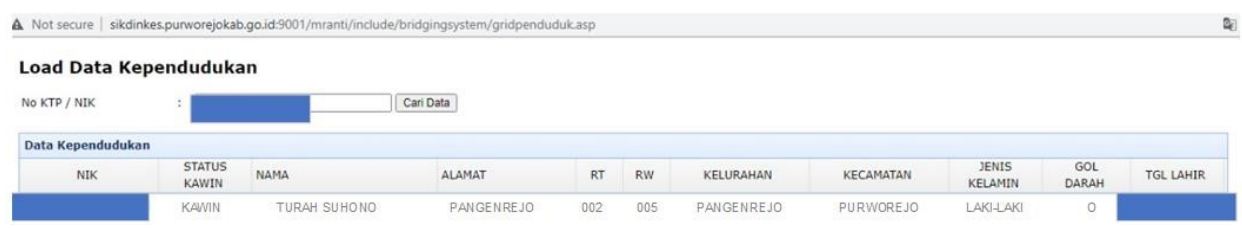

Gambar 5 Pengecekan data kependudukan dari aplikasi SIMPUS.

\section{Kesimpulan}

Sebanyak 134 data primer yang dikelola oleh 35 OPD di lingkungan Pemerintah Kabupaten Purworejo, berdasarkan identifikasi atribut yang ada dari data primer untuk dapat dikomunikasikan antar OPD untuk kepentingan interoperabilitas sistem informasi berhasil dihasilkan. Data primer yang dihasilkan tersebut sudah dipetakan secara ketugasan dan tanggung jawabnya terhadap 35 OPD berdasarkan siapa dan apa perannya dengan menggunakan tabel RACI.

Berdasarkan hasil pemetaan data primer telah dibuat penyusunan skema pemetaan interoperabilitas sistem informasi. Selanjutnya pemetaan tersebut dapat menjadi dasar dalam rumusan perancangan strategis sistem informasi. Pemetaan interoperabilitas sistem informasi tersebut dapat digunakan sebagai dasar pengambilan keputusan dalam pengembangan sistem informasi yang merupakan bagian dari pelaksanaan e-government menuju Pemerintah Kabupaten Purworejo Smart City.

Pengujian interoperabilitas sistem informasi pada 3 aplikasi yaitu : aplikasi SIAK sebagai provider data kependudukan, aplikasi Dashboard Web Service sebagai pemberi layanan web service data kependudukan, dan aplikasi SIMPUS sebagai client. Hasil penelitian ini dapat dijadikan bahan dalam implementasi pengembangan interoperabilitas sistem informasi yang akan datang.

\section{Pustaka}

1 "Peraturan presiden nomor 39 tahun 2019 tentang satu data indonesia." 2019. [Online]. Available: https://jdih.setkab.go.id/PUUdoc/175860/Perpres_Nomor_39_Tahun_2019. pdf

2 "Peraturan daerah kabupaten purworejo nomor 12 tahun 2016 tentang rencana pembangunan jangka menengah daerah (rpjmd) kabupaten purworejo tahun 20162021." 2016. [Online]. Available: https://bappeda.purworejokab.go.id/download/file/ RENSTRA_BAPPEDA.pdf

3 S. Palupi, "Purworejo smartcity melalui penyediaan laboratorium produksi data statistik di kabupaten." 2019. [Online]. Available: https://bpsdmd.jatengprov.go.id/eproper/ cetakinovasi $/$ index_pdf.php/?nourut $=2386$

4 "Peraturan bupati purworejo nomor 52 tahun 2017 tentang penyelenggaraan pemerintahan berbasis elektronik (e-government) di lingkungan pemerintah kabupaten purworejo." 2016. 
5 A. Zainal, "Metodologi penelitian pada bidang ilmu komputer dan teknologi informasi; konsep, teknik, dan aplikasi," 2007.

6 M. R. Romdoni, "Perancangan portal interoperabilitas e-government sebagai platform integrasi sistem informasi pemerintahan kota denpasar," Lontar Komputer: Jurnal Ilmiah Teknologi Informasi, 2013.

7 N. Ruswianto, E. Utami, dan M. R. Arief, "Perancangan data primer untuk layanan e-government berbasis ketugasan dengan pendekatan model diagram raci (study kasus: Pemerintah kota magelang)," SEMNASTEKNOMEDIA ONLINE, vol. 6, no. 1, pp. 1-4, 2018.

8 M. H. Othman dan R. Razali, "Electronic government systems interoperability model," Journal of Telecommunication, Electronic and Computer Engineering (JTEC), vol. 9, no. 3-4, pp. 1-9, 2017.

9 "Rancangan peraturan menteri tahun 2020 tentang interoperabilitas data." 2020. [Online]. Available: https://web.kominfo.go.id/sites/default/files/users/4752/ DraftRancanganPeraturanMenkominfotentangInteroperabilitasData.pdf

10 D. I. Permatasari, "Pengujian aplikasi menggunakan metode load testing dengan apache jmeter pada sistem informasi pertanian," JUSTIN (Jurnal Sistem dan Teknologi Informasi), vol. 8, no. 1, pp. 135-139, 2020. 